$J 7 \mathrm{A3}$

opy 1 



\section{Geological Survey of Alabama}

EUGENE ALLEN SMITH, State Geologist

\section{A FOREST CENSUS OF ALABAMA}

BY GEOGRAPHICAL DIVISIONS

(Supplementary to Monograph 8)

BY

ROLAND M. HARPER

[Reprinted from the Proceedings of the Society of American Foresters, Vol. XI, No, 2. 1916]

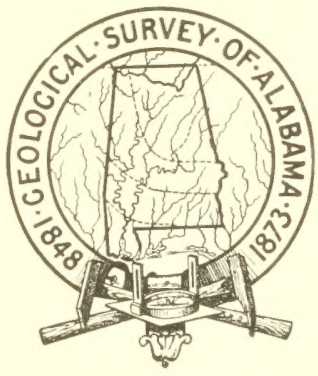

UNIVERSITY, ALABAMA

1916 


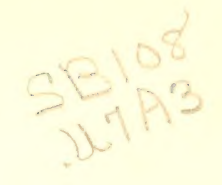

\title{
A FOREST CENSUS OF ALABAMA BY GEOGRAPHICAL DIVISIONS
}

\author{
By Dr. Roland M. Harper, College Point, N. Y.
}

In a report on forests, prepared in 1913 for the Geological Survey of Alabama, ${ }^{1}$ the writer divided the State into 15 main divisions and a few of lesser rank, listed the trees of each division with approximate percentages of abundance in the original and present forests, and gave some statistics of the amount of forest, density of population, number and capacity of sawmills, etc. The estimates of the percentage of woodland in each region were guesses based mostly on personal observation, for I had not then noticed that the government census reports for 1910 (and earlier) gave the amount of land in farms and woodland on farms for each county, from which the per cent of forest in any region could be computed more accurately.

Two other sorts of statistics in government reports which would have made my treatment more complete were likewise overlooked. The census reports give the amount spent for fertilizers in each county during the year immediately preceding the census year, and the ratio between that and the acreage of improved land gives a pretty fair index of the fertility of the soil. 2 Lastly, a report on the lumber industry of the United States, published by the Bureau of Corporations of the Department of Commerce and Labor in January, 1913, contains a careful estimate of the acreage and standing timber owned or controlled by lumbermen in each of the more important lumber-producing States on January 1, 1911. The timber is divided into a few groups of species, and in the case of Alabama and a few other states the State is subdivided into several groups of counties, corresponding approximately with natural divisions.

Some of the geographical divisions described in my 1913 report are so narrow that they do not cover as much as half of any one county, and conseguently the available county statisties camnot very well be applied to them. In the present paper these narrow belts are combined with adjoining ones, thereby reducing the number of divisions to ten, as was done in a preliminary paper on the subject in the Southern Jumberman for April 5, 1913, and in the abstract in American Forestry previously

${ }^{1}$ Monograph S, or Economic Bota of Alabama, part 1: see abstract in American Forestry for October, 1913, and review in Forestry Quarterly for December, 1913.

see Science II. 42:500-503. oct. 8, 1915 .

(208) 
referred to. The map used herewith is very similar to that used in the Southern Lumberman and identical with that in American Forestry and

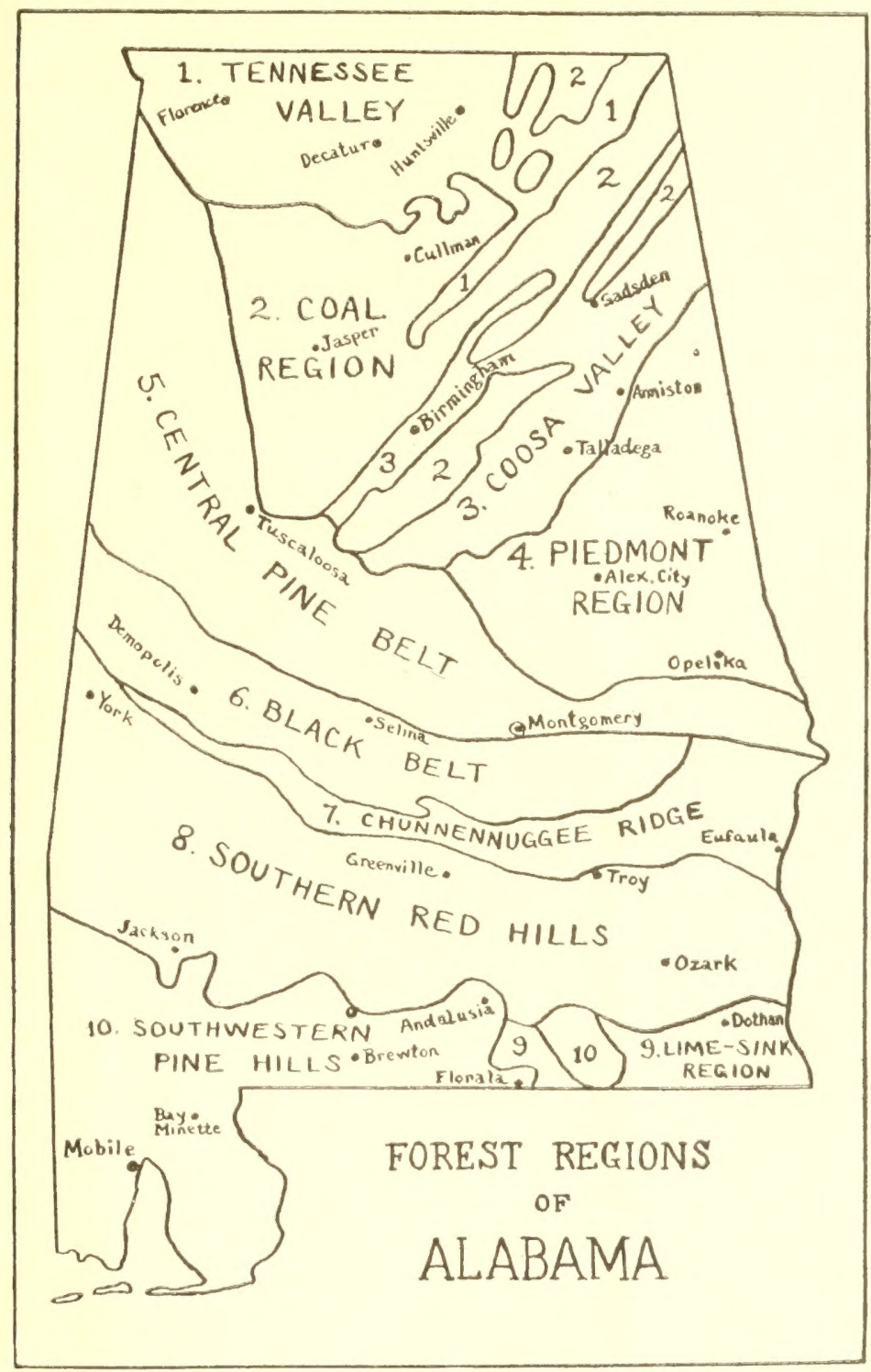

the Forestry Quarterly. (It happens that eight of the ten statistical divisions of Alabama defined on page 285 of the Bureau of Corporations 
report on standing timber correspond about as closely as divisions following county lines can with the same number on this map, and they must have been laid out with geographical contrasts in view. But the third and fifth are so heterogeneous as to be of no value for present purposes, and just what determined their selection is not apparent.)

The regions as here defined, with their areas, are as follows. Their location is sufficiently indicated on the map, and for notes on soil, topography, climate, etc., the reader is referred to the publications already mentioned.

1. The Tennessee Valley, including the "barrens" of the Highland Rim on the north-4,900 square miles.

2. The coal region, which can be subdivided into the plateau and basin regions - 6,400 square miles.

3. The Coosa or Appalachian Valley region-4,000 square miles.

4. The Piedmont region, with the Blue Ridge along its northwestern edge-5,400 square miles.

5. The central pine belt, with three subdivisions- $\gamma, 450$ square miles.

6. The black belt or central prairie region-4,300 square miles.

$\%$. The Chunnennuggee Ridge and blue marl region-2,300 square miles.

s. The southern red hills, together with the post-oak flatwoods on the north and the lime hills on the southwest-9,635 square miles.

9. The lime-sink or wire-grass region-1,350 square miles.

10. The southwestern pine hills, together with the Mobile delta and the coast strip-5,550 square miles.

The census of 1910 divides the land area of each state into land not in farms, improved land in farms, woodland on farms, and other unimproved land in farms. In a state like Alabama, which was originally almost completely wooded, except for a few prairies in the central portion (now nearly all under cultivation) and small marshes along the coast, the sum of the land not in farms and the woodland on farms gives a pretty elose approximation to the present forest area. The "other unimproved land" is defined as including "brush land, rough or stony land, swamp land, and any other land which is not improved or in forest." The inclusion of swamp land in this category seems unfortunate, for in the South a swamp is always a forest; but the amount of forest slighted in this way may be just about counterbalanced by marshes, uncultivated prairies, towns and cities, roads, and farms overlooked by the enumerators.

Of the 32,818,560 acres of land in Alabama, the sum of the land not in farms and the woodland on farms, according to the census of 1910 , was 
$21,531,012$ acres, or about 65 per cent. Of this, $10,879,000$ acres of forest and 435,000 acres with young timber or none at all (a little more than half the forest area of the State, or about 33 per cent of the total area) belonged to Iumbermen on January 1, 1911, according to the Bureau of Corporations report. The total stand of timber on their land was 56,$300,000,000$ feet, or 5,200 feet per acre. If the density of the rest of the forest is the same, the State total would be about 112 billion feet.

In the statistics for Alabama in the standing-timber report the trees are divided into three groups, namely, longleaf pine (which doubtless includes slash pine also), shortleaf and loblolly (presumably including also black and spruce pine), and cypress and hardwoods. It is evident that the lumbermen tend to specialize in longleaf pine, the most useful tree in the State, for the percentage of that in their holdings is considerably higher than the writer's estimate for the whole State and the several subdivisions. The percentages of hardwoods given are too low for the total stand of timber, doubtless because any one species of hardwood usually grows so scattered that it does not pay a lumberman to buy much land for the sake of the hardwood on it. If we multiply the figures for shortleaf and loblolly pine in that report by two and those for cypress and hardwoods by four, we will get a fairly close approximation to the total standing timber in each region-probably as nearly correct as could be obtained by using any other arbitrary multipliers throughout, for it makes the percentages of the pines too high in some regions and too low in others, but about right for the whole State. The percentages obtained in this manner can now be used as a check on my 1913 figures, which were derived in a rather crude manner (since improved on) from my field notes.

The following table is intended to partly supersede the list of trees on pages 189-191 and the table on page 195 of my report on the forests of Alabama. It gives for each of the ten regions and for the whole State the percentage of forests in 1910, the expenditure for fertilizer in 1909 per acre of improved land, the percentage of evergreens, and the percentage of the present forest made up by each species of tree (exclusive of the smaller and rarer species). Percentages are given only to the nearest integer, and consequently all below $1 / 2$ are represented by 0 ; but where a given species is believed not to occur at all in a certain region, or only along its edges, dots are used instead.

In my 1913 report one could ascertain in which region any species was most abundant only by looking through the 19 regional lists; but this table shows it at a glance by bringing the percentages together in parallel columns. The highest percentages in each row are printed in 
212 PROCEEDINGS OF THE SOCIETY OF AMERICAN FORESTERS

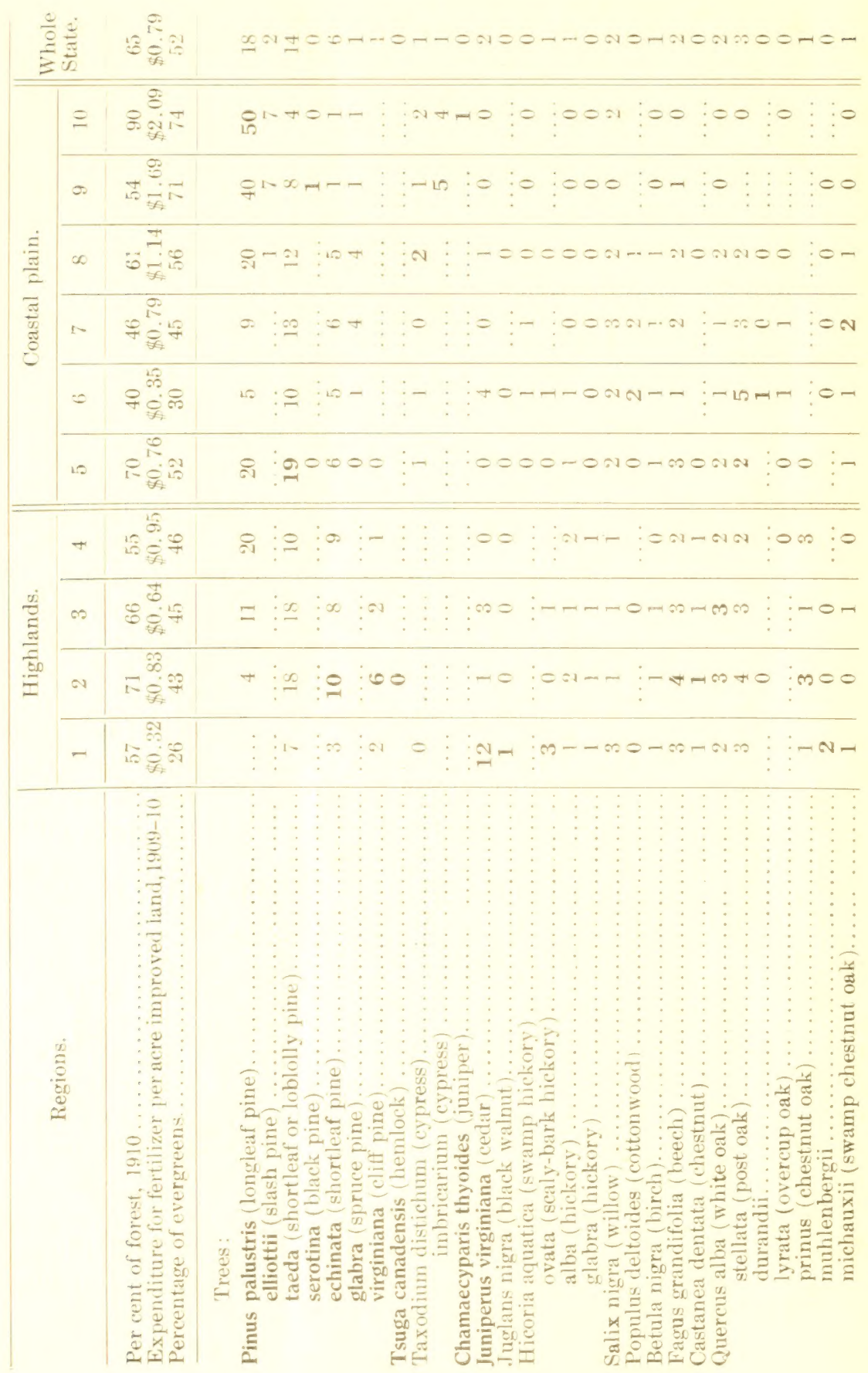


FOREST CENSUS OF ALABAMA

213

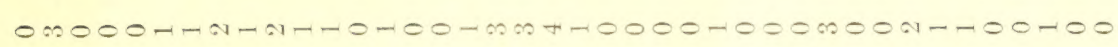

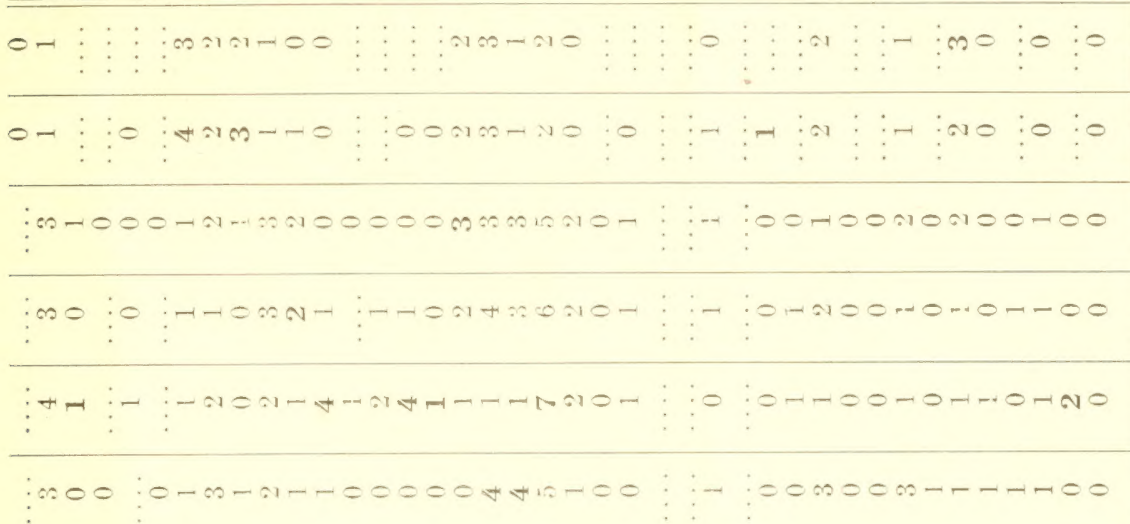

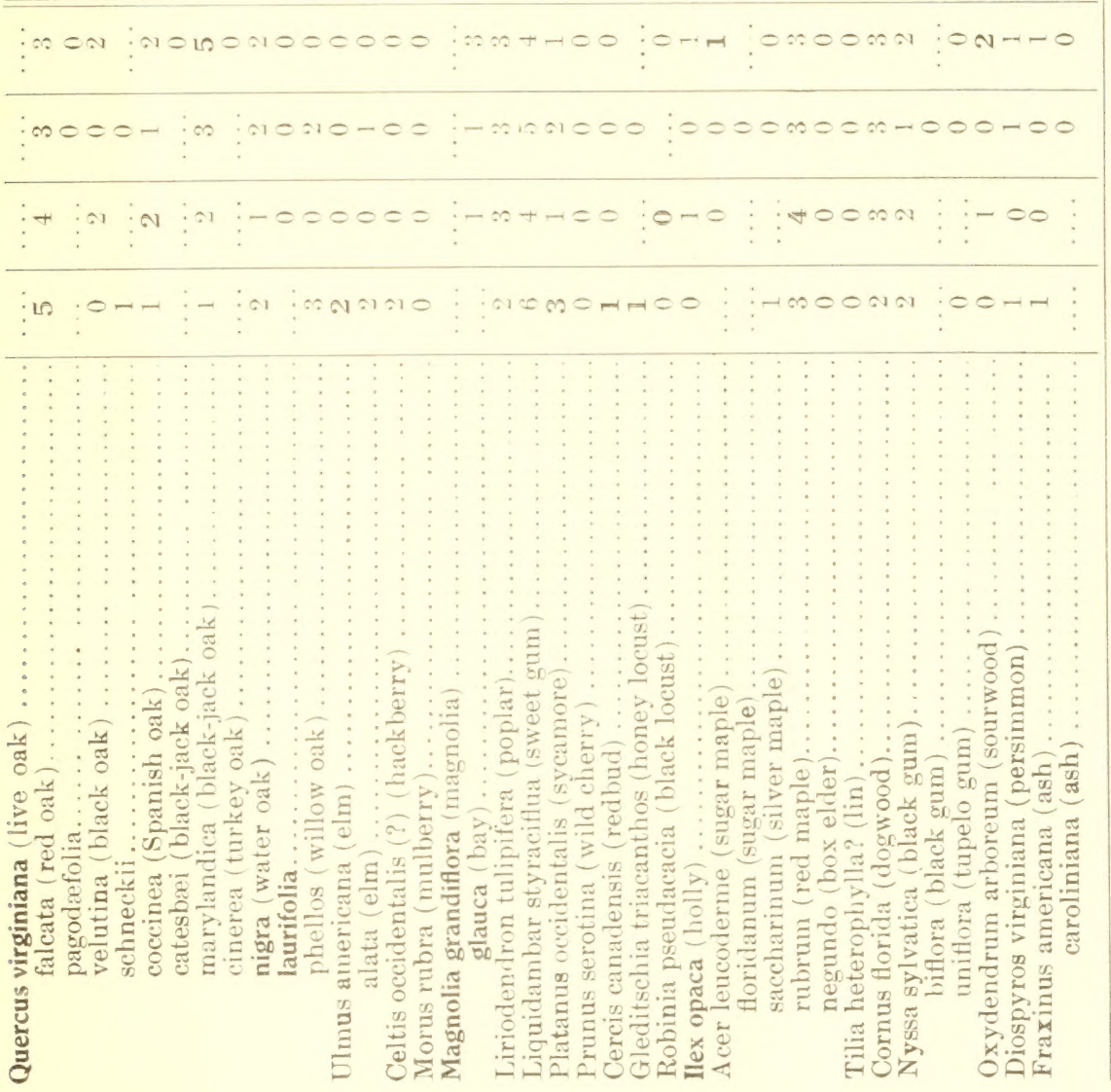




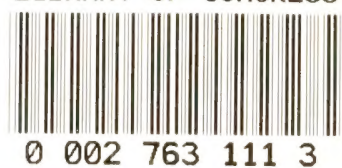

heavier type (except where there is uncertainty about which is the highest) to aid the eye in picking them out, and also to indicate the most characteristic species in each region when one is running down one column at a time.

The technical names used are the same as in the 1913 report, and correspond in nearly every case with those in Sudworth's Check List, Mohr's Plant Life of Alabama, Small's Flora of the Southeastern United States, and Sargent's Manual. The common names are those used throughout the South, but not necessarily in other parts of the country. The names of evergreens are printed in heavier type, as in many of the writer's previous publications.

The probable quantity of any species in the State is of course the product of its State percentage and the total stand of timber previously mentioned. The evergreen percentages for the several regions are obtained by adding those in the columns and allowing a little more for rarer evergreens not listed.

Although only about half the known arborescent species in the State are represented in this table, it includes practically all that are of any commercial importance. It will be seen at a glance that the pines predominate, as in most of the other States bordering the Atlantic and Gulf coasts. If the figures are correct, no hardwood species constitutes as much as 8 per cent of the forests of any one region, as here defined (this would not be true of some of the smaller divisions in the more complete report, however), or 5 per cent of the standing timber of the whole State.

The evergreen percentages are generally highest in the regions with the poorest soils, as indicated by the amount of land remaining in forest and the sums spent for fertilizers on the cultivated areas. In the primeval forests the differences in evergreen percentages between the rich and poor regions would doubtless have been greater, for in the regions with rich soils most of the hardwoods have been destroyed to make room for crops, while in the sandy pine lands a large part of the pine has been removed by lumbermen, and the hardwoods, which are there chiefly confined to swamps, have been comparatively little disturbed.

It would be interesting if we could make an estimate for each region of the average stand of timber and its rate of growth and the rate at which it is being cut, but there are no sufficient data on these points at present. The timber is probably growing faster than it is being cut in some of the regions, but not in most of them. The most rapid growth is presumably on the richer soils, but the longleaf pine, the species most in demand, prefers the poorer soils and is probably not holding its own. 

LIBRARY OF CONGRESS

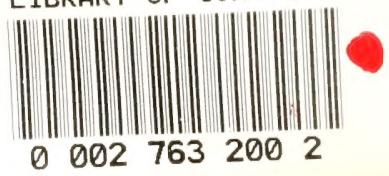

